\title{
PENGARUH KECERDASAN LOGIK MATEMATIKA DAN MINAT BELAJAR TERHADAP PRESTASI BELAJAR MATEMATIKA
}

\author{
ARFATIN NURRAHMAH \\ arfatinnurrahmah@gmail.com \\ Program Studi Pendidikan Matematika, Fakultas Teknik, Matematika, dan IPA \\ Universitas Indraprasta PGRI
}

\begin{abstract}
Abstrak. Tujuan penelitian ini adalah untuk mengetahui pengaruh kecerdasan logik matematika dan minat belajar terhadap prestasi belajar matematika. Metode penelitian yang digunakan adalah metode survey. Sampel berukuran 150 siswa kelas VIII dari 3 SMP Negeri di Kecamatan Menteng yaitu SMP N 280, SMP N 8, dan SMP N 1, dipilih dengan menggunakan teknik simple random sampling. Pengumpulan data dilakukan dengan menggunakan teknik penyebaran angket dan teknik tes. Analisis data dengan menggunakan analisis jalur. Uji statistik yang digunakan adalah uji t. Berdasarkan hasil penelitian dapat disimpulkan bahwa 1) Kecerdasan logik matematik berpengaruh secara langsung dan signifikan terhadap prestasi belajar matematika siswa, 2) Minat belajar berpengaruh secara langsung dan signifikan terhadap prestasi belajar matematika siswa, 3) Kecerdasan logik berpengaruh secara langsung dan signifikan terhadap minat belajar siswa, dan 4) Kecerdasan logik matematik memiliki pengaruh secara tidak langsung dan signifikan terhadap prestasi belajar matematika melalui minat belajar siswa.
\end{abstract}

Kata kunci: Kecerdasan Logik Matematika, Minat Belajar, Prestasi Belajar Matematika.

\section{PENDAHULUAN}

Proses belajar mengajar merupakan salah satu kegiatan yang sangat penting dalam proses pendidikan di sekolah. Dalam kegiatan belajar mengajar ini, terdapat suatu proses yang mengandung serangkaian perbuatan guru dan siswa atas dasar hubungan timbal balik yang berlangsung dalam situasi edukatif untuk mencapai tujuan tertentu. Dalam hal ini bukan hanya penyampaian pesan berupa materi pelajaran, melainkan penanaman sikap dan nilai pada diri siswa yang sedang belajar. Belajar merupakan keterlibatan mental dan kerja siswa sendiri. Penjelasan dan pemeragaan semata tidak akan membuahkan hasil belajar yang langgeng. Terutama dalam pelajaran matematika karena matematika sebagai ilmu dasar yang terpakai di segala bidang ilmu pengetahuan, saat ini telah berkembang pesat baik materi maupun kegunaannya. Prestasi belajar matematika seorang siswa dapat dipengaruhi oleh beberapa faktor yaitu diantaranya adalah faktor eksternal dan faktor internal. Faktor eksternal adalah hal-hal yang berhubungan dengan prestasi belajar yang berasal dari luar diri siswa seperti guru, kurikulum, metode, media belajar, sarana belajar, lingkungan dan sebagainya. Sedangkan faktor internal yaitu halhal yang berhubungan dengan prestasi belajar yang berasal dari dalam diri siswa seperti kecerdasan, minat, bakat, sikap, motivasi, kebiasaan belajar, evaluasi diri dan sebagainya.

Kecerdasan merupakan salah satu faktor internal yang dianggap mempengaruhi prestasi belajar siswa. Menurut Gardner yang dikutip oleh Campbell (2005:2), kecerdasan adalah: "Kemampuan untuk menyelesaikan masalah yang terjadi dalam kehidupan manusia, kemampuan untuk menghasilkan persoalan-persoalan baru untuk diselesaikan, dan kemampuan untuk menciptakan sesuatu atau menawarkan jasa yang akan menimbulkan penghargaan dalam budaya seseorang". Kecerdasan mempunyai pengaruh yang cukup penting dalam hal pencapaian prestasi belajar. Siswa yang cerdas akan lebih berhasil dalam kegiatan belajar, karena ia lebih mudah menangkap dan memahami pelajaran dan lebih mudah mengingat-ingatnya. Anak yang cerdas akan lebih mudah 
berpikir kreatif dan lebih cepat mengambil keputusan. Salah satu kecerdasan yang mempengaruhi prestasi belajar matematika adalah kecerdasan logik matematika, yang diperlukan untuk memecahkan setiap persoalan dalam pelajaran matematika. Seseorang yang memiliki tingkat kecerdasan logik matematika yang relatif tinggi cenderung lebih baik prestasi belajarnya dibandingkan dengan seseorang yang memiliki tingkat kecerdasan logik matematika yang relatif rendah. Namun demikian, faktor kecerdasan bukanlah satu-satunya faktor yang menentukan prestasi belajar yang akan dicapai siswa. Faktor lain yang dianggap mempengaruhi prestasi belajar adalah minat belajar siswa.

Minat menurut Slameto (2011:191) adalah suatu rasa lebih suka dan rasa ketertarikan pada suatu hal atau aktivitas tanpa ada yang menyuruh. Siswa yang memiliki minat terhadap subjek tertentu cenderung untuk memberikan perhatian yang lebih besar terhadap subjek tersebut. Minat yang besar terhadap sesuatu ini merupakan modal yang besar untuk mencapai tujuan yang diinginkan. Belajar dengan minat akan mendorong siswa belajar lebih baik daripada belajar tanpa minat. Minat ini timbul apabila siswa tertarik akan sesuatu karena sesuai dengan kebutuhannya atau merasa bahwa sesuatu yang akan dipelajari dirasakan bermakna bagi dirinya. Namun demikian minat tanpa adanya usaha yang baik maka belajar juga sulit untuk berhasil.

Demikian juga dalam hal belajar matematika, siswa yang memiliki minat besar terhadap matematika, mereka akan senang belajar matematika, suka bertanya jika tidak tahu, rajin mengerjakan pekerjaan rumah dan membeli buku penunjang, dll. Minat belajar yang besar terhadap matematika cenderung menghasilkan prestasi belajar yang tinggi. Sedangkan siswa yang memiliki minat dan keingintahuan yang kurang untuk menekuni pelajaran matematika akan kesulitan dalam belajar matematika. Hal ini ditandai dengan masih rendahnya prestasi belajar yang dicapai.Hal-hal yang berhubungan dengan prestasi belajar baik faktor eksternal maupun faktor internal memang sangat berpengaruh terhadap prestasi belajar matematika itu sendiri. Faktor internal merupakan hal-hal yang berasal dari dalam diri siswa yang dapat diukur, dimana faktor kecerdasan logik matematika dan minat belajar lah yang menurut penulis sangat berperan dalam keberhasilan belajar dari seorang siswa. Berdasarkan penjelasan dari latar belakang diatas, maka penulis akan melakukan penelitian dengan judul "Pengaruh Kecerdasan Logik Matematik dan Minat Belajar Terhadap Prestasi Belajar Matematika Siswa Kelas VIII SMP Negeri SeKecamatan Menteng".

\section{TINJAUAN PUSTAKA}

\section{Prestasi Belajar Matematika}

Guru berperan penting dalam proses belajar di sekolah sehingga tujuan pembelajaran dapat tercapai. Setelah siswa melakukan kegiatan belajar maka mereka akan memperoleh apa yang disebut prestasi belajar. Menurut Sudjana (1995:22), prestasi belajar adalah kemampuan yang dimiliki siswa setelah ia menerima pengalaman belajarnya. Menurut Dimyati dan Dimyati dan Mudjiono (2006:3), prestasi belajar merupakan hasil dari suatu interaksi tindak belajar dan tindak mengajar. Masih menurut Sudjana (1995:3), prestasi belajar itu juga merupakan perubahan tingkah laku yang mencangkup bidang kognitif, afektif dan psikomotorik. Dari definisi tersebut dapat dikatakan bahwa prestasi belajar adalah tingkat penguasaan siswa yang mencangkup ranah kognitif, afektif, dan psikomotorik.Bukti bahwa seseorang telah belajar ialah terjadinya perubahan tingkah laku pada orang tersebut, misalnya dari tidak tahu menjadi tahu, dan dari tidak mengerti menjadi mengerti. Hamalik (2009:30) menyatakan bahwa prestasi belajar akan tampak pada setiap perubahan pada beberapa aspek, antara lain: 1) pengetahuan, 2) pengertian, 3) kebiasaan, 4) keterampilan, 5) apresiasi, 6) emosional, 7) hubungan sosial, 8) jasmani, 9) etis dan budi pekerti, 10) sikap. 
Menurut James (Hudoyono, 1990:76) matematika adalah ilmu tentang logika mengenai bentuk susunan besaran dan konsep-konsep yang saling berhubungan satu sama lainnya, dengan jumlah yang banyaknya terbagi dalam tiga bidang yaitu aljabar, analisis dan geometri. Matematika timbul karena pikiran-pikiran manusia yang berhubungan dengan ide, proses dan penalaran. Dewasa ini berkembang sangat pesat baik materi maupun kegunaannya. Matematika terdiri dari empat wawasan yang luas yaitu: 1) Arimatika mencakup kajian bilangan dan hitungan, 2) Aljabar mencakup kajian tentang bahasa simbol operasi dan relasi, 3) Geometri mencakup kajian bentuk, ukuran ruang dan keterhubungan, dan 4) Analisa.

Salah satu cabang matematika adalah geometri. Menurut Kamus Besar Bahasa Indonesia (2001:355), geometri adalah cabang matematika yang menerangkan sifat garis, sudut, bidang, dan ruang. Materi tentang kubus, balok, prisma dan limas merupakan salah satu pokok bahasan dari geometri, dimana Standar Kompetensi yang diharapkan adalah memahami sifat-sifat kubus, balok, prisma, limas dan bagian-bagiannya serta menentukan ukurannya.

Penguasaan matematika dapat dianggap sebagai suatu produk dari suatu proses. Sebagaimana diketahui, proses tercapainya tingkat penguasaan matematika berhubungan dengan kemampuan matematika yang telah dimiliki sebelumnya, yang dapat menunjang pemahaman dan penyerapan bahan pelajaran yang dipelajarinya, yang nanti hasilnya dapat dilihat dari prestasi belajarnya.Dari beberapa pendapat tentang prestasi adalah hasil dari suatu kegiatan yang telah dikerjakan, diciptakan, baik secara individual maupun kelompok. Prestasi tidak akan pernah dihasilkan selama seseorang tidak melakukan suatu kegiatan. Dalam kenyataan, untuk mendapatkan prestasi tidak semudah yang dibayangkan, tetapi penuh perjuangan dengan berbagai rintangan dan tantangan yang harus dihadapi untuk mencapainya. Hanya dengan keuletan dan optimisme yang dapat membantu untuk mencapainya, oleh karena itu wajarlah pencapaian prestasi itu harus dengan keuletan belajar. Berdasarkan pendapat para ahli tentang belajar, konsep matematika, dan prestasi belajar yang telah diuraikan maka yang dimaksud dengan prestasi belajar matematika dalam penelitian ini adalah kemampuan yang dimiliki siswa dalam belajar matematika mencangkup ranah kognitif, afektif, dan psikomotorik berdasarkan hasil dari suatu interaksi tindak belajar, terutama pada pokok bahasan geometri (kubus, balok, prisma dan limas).

\section{Kecerdasan Logik Matematika}

Kecerdasan memiliki pengertian yang luas. Anak cerdas bukanlah anak yang pintar di bidang akademik, namun juga mencangkup seseorang dalam memecahkan masalahnya. Seperti yang dikutip oleh Uno dan Kuadrat (2009:11), Gardner seorang psikolog terkemuka dari Harvard University mengungkapkan bahwa kecerdasan logik matematika memuat kemampuan seseorang dalam berpikir menurut aturan logika, memahami dan menganalisis pola angka-angka, serta memecahkan masalah dengan menggunakan kemampuan berpikir.Yaumi (2012:15) dalam buku yang berjudul Pembelajaran Berbasis Multiple Intelligences menjelaskan bahwa kecerdasan logik matematik adalah kemampuan yang berkenaan dengan rangkaian alasan, mengenal pola pola dan aturan. Kecerdasan ini merujuk pada kemampuan untuk mengeksploitasi polapola, kategori-kategori dan hubungan dengan memanipulasi objek atau simbol untuk melakukan percobaan dengan cara yang terkontrol dan teratur.

Menurut Piaget yang dikutip oleh Campbell dkk (2005:40) kecerdasan logik matematik dimulai dengan interaksi-interaksi seorang anak kecil dengan objek-objek di lingkungannya, penemuan angka, peralihan dari objek-objek yang konkrit ke simbolsimbol yang abstrak, manipulasi abstraksi dan akhirnya pertimbangan dari pernyataan- 
pernyataan secara hipotesis dalam suatu hubungan-hubungan dan implikasiimplikasinya.Menurut Gardner yang dikutip oleh Campbell dkk (2005:2) kecerdasan logik matematik merupakan kemampuan dalam menghitung, mengukur dan mempertimbangkan proposisi dan hipotesis, serta menyelesaikan operasi-operasi matematis.

Dari pendapat-pendapat para ahli yang disebutkan di atas, maka dalam kecerdasan logik matematika dirumuskan sebagai kemampuan seseorang dalam berpikir menurut aturan logika, memahami dan menganalisis pola angka-angka, memecahkan masalah dengan menggunakan kemampuan berpikir, mengenal pola - pola dan aturan tertentu, menghitung, mengukur dan mempertimbangkan proposisi dan hipotesis, serta menyelesaikan operasi-operasi matematis.

\section{Minat Belajar}

Secara bahasa menurut KKBI, minat berarti kecendrungan hati yang tinggi terhadap sesuatu. Minat merupakan sifat yang relatif menetap pada diri seseorang. Menurut Purwanto (2010:56), minat mengarahkan perbuatan kepada suatu tujuan dan merupakan dorongan bagi perbuatan itu. Pendapat ini senada dengan yang dikemukakan oleh Syah (2010:133) yang mengatakan bahwa minat berarti kecendrungan dan kegairahan yang tinggi atau keinginan yang besar terhadap sesuatu. Minat menurut Slameto (2003:182), adalah suatu rasa lebih suka dan rasa keterikatan pada suatu hal atau aktivitas, tanpa ada yang menyuruh. Minat pada dasarnya adalah penerimaan akan suatu hubungan antara diri sendiri dengan sesuatu di luar diri. Semakin kuat atau dekat hubungan tersebut, maka semakin besar minat.

Menurut Nuryanti (2008:59) minat adalah kecenderungan seseorang terhadap sesuatu atau bisa dikatakan apa yang disukai seseorang untuk dilakukan. Pada dasarnya setiap orang akan lebih senang melakukan sesuatu yang sesuai dengan minatnya (yang disukai) daripada melakukan sesuatu yang kurang disukai. Kecerdasan Logik Matematik memuat kemampuan seseorang dalam berpikir secara induktif dan deduktif, berpikir menurut aturan logika, memahami dan menganalisis pola angka-angka, serta memecahkan masalah dengan menggunakan kemampuan berpikir. Peserta didik dengan kecerdasan logik matematik yang tinggi cenderung menyenangi atau memiliki minat dalam kegiatan menganalisis dan mempelajari sebab akibat terjadinya sesuatu. Minat belajar adalah suatu kecenderungan perasaan suka/senang, tertarik serta memiliki perhatian lebih, keinginan yang besar dan keaktifan seseorang terhadap sesuatu dalam kegiatan belajar.

Uno dan Kuadrat (2010:11) menyatakan bahwa peserta didik yang memiliki kecedasan logik matematik tinggi cenderung menyukai aktivitas berhitung dan memiliki kecepatan tinggi dalam menyelesaikan problem matematika. Apabila kurang memahami, mereka akan cenderung berusaha untuk bertanya dan mencari jawaban atas hal yang kurang dipahaminya tersebut. Berdasarkan penjabaran di atas, dengan kata lain dapat dikatakan bahwa kecerdasan logik matematika akan mempengaruhi minat belajar.

Dari berbagai penjelasan di atas maka dapat disimpulkan bahwa minat belajar adalah suatu kecenderungan perasaan suka/senang, tertarik serta memiliki perhatian lebih, keinginan yang besar dan keaktifan seseorang terhadap sesuatu dalam kegiatan belajar.

\section{METODE}

Penelitian ini menggunakan teknik analisis jalur untuk menguji besarnya sumbangan (kontribusi) yang ditujukan oleh koefisien jalur pada setiap diagram jalur dari hubungan kausal antar variabel bebas $\left(\mathrm{X}_{1}\right.$ dan $\left.\mathrm{X}_{2}\right)$ dan variabel Terikat $\left(\mathrm{X}_{3}\right)$. Model 
hubungan antara ketiga variabel penelitian ini dapat digambarkan dalam bentuk konstelasi permasalahan sebagai berikut:

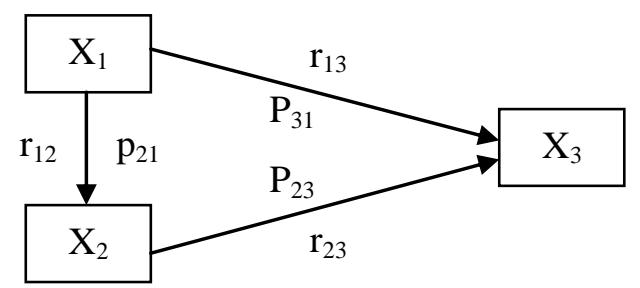

Gambar 1. Konstelasi Masalah Penelitian

$\mathrm{X}_{1}=$ Kecerdasan Logik Matematik

$\mathrm{X}_{2}=$ Minat Belajar

$\mathrm{X}_{3}=$ Prestasi Belajar Matematika

\section{HASIL DAN PEMBAHASAN} Analisis Deskriptif Data

Tabel 1. Ringkasan Deskripsi Statistik

\begin{tabular}{|l|r|r|r|}
\hline & \multicolumn{1}{|c|}{$\mathbf{X}_{\mathbf{1}}$} & $\mathbf{X}_{\mathbf{2}}$ & $\mathbf{X}_{\mathbf{3}}$ \\
\hline $\mathrm{N} \quad$ Valid $\quad$ Missing & 150 & 150 & 150 \\
Mean & 0 & 0 & 0 \\
Median & 81,3067 & 97,0200 & 84,5800 \\
Mode & 83,0000 & 96,0000 & 87,0000 \\
Std. Deviation & 86,00 & 96,00 & 83,00 \\
Minimum & 9,48467 & 1,55675 & 8,92344 \\
Maximum & 43,00 & 56,00 & 43,00 \\
\hline
\end{tabular}

Dari data hasil tes kecerdasan logik matematik yang dilakukan terhadap 150 orang responden dalam penelitian ini, rentangan nilai terletak pada angka minimum dan maksimum 43,00 - 97,00. Rentangan ini memberikan gambaran bahwa nilai terendah mengenai kecerdasan logik matematik adalah 43,00, sedangkan nilai maksimumnya adalah 97,00. Selanjutnya nilai mean atau rata-rata jawaban responden adalah sebesar 81,3067 . Hal ini mengindikasikan bahwa kecerdasan logik matematik berkencenderungan positif dan menunjukkan angka yang cukup tinggi. Sementara itu, nilai tengah (median) dan nilai yang sering muncul (modus) masing- masing adalah sebesar 83,00 dan 86,00.

Dari data hasil angket minat belajar yang dilakukan terhadap 150 orang responden dalam penelitian ini, rentangan nilai terletak pada angka minimum dan maksimum 56,00 - 140,00. Rentangan ini memberikan gambaran bahwa nilai terendah mengenai minat belajar adalah 56,00 yang menunjukkan bahwa minat belajar matematika siswa ini termasuk rendah, sedangkan nilai maksimumnya adalah 140,00 yang menunjukkan bahwa minat belajar siswa ini termasuk tinggi. Selanjutnya nilai mean atau rata-rata jawaban responden adalah sebesar 97,02. Hal ini mengindikasikan bahwa minat belajar siswa terhadap ,matematika berkencenderungan positif dan menunjukkan angka yang cukup tinggi. Sementara itu, nilai tengah (median) dan nilai yang sering muncul (modus) masing- masing adalah sebesar 96,00 dan 96,00.

Dari data hasil tes prestasi belajar yang dilakukan terhadap 150 orang responden dalam penelitian ini, rentangan nilai terletak pada angka minimum dan maksimum 43,00 
- 100,00. Rentangan ini memberikan gambaran bahwa nilai terendah mengenai prestasi belajar adalah 43,00, sedangkan nilai maksimumnya adalah 100,00 yang menunjukkan bahwa ada siswa yang dapat menjawab semua pertanyaan dengan benar. Selanjutnya nilai mean atau rata-rata jawaban responden adalah sebesar 84,580. Hal ini mengindikasikan bahwa prestasi belajar siswa terhadap matematika berkencenderungan positif dan menunjukkan angka yang cukup tinggi. Sementara itu, nilai tengah (median) dan nilai yang sering muncul (modus) masing- masing adalah sebesar 87,00 dan 83,00.

\section{Pengujian Prasyarat Analisis Data}

\section{Uji Normalitas}

Uji normalitas dilakukan untuk mengetahui apakah data yang diperoleh peneliti berasal dari populasi berdistribusi normal atau tidak. Hal ini dilakukan sebagai syarat jika pengujian dilakukan dengan menggunakan statistik parametrik. Dalam melakukan uji normalitas peneliti menggunakan SPSS 20 sebagai alat bantu. Dalam hal ini peneliti menggunakan Kolmogorov Smirnov dalam melakukan pengujian.

Pengujian normalitas data masing-masing sampel diuji melalui hipotesis:

$\mathrm{H}_{0}$ : Data berasal dari populasi yang berdistribusi normal

$\mathrm{H}_{1}$ : Data berasal dari populasi yang tidak berdistribusi normal

Kriteria pengujian hipotesis: tolak $\mathrm{H}_{1}$ dan terima $\mathrm{H}_{0}$ jika nilai probabilitas $\mathrm{p}>$ 0,05 serta terima $\mathrm{H}_{1}$ dan tola $\mathrm{H}_{0}$ jika nilai probabilitas $\mathrm{p}<0,05$.

Tabel 2. Ringkasan Uji Normalitas

\begin{tabular}{|c|c|c|c|}
\hline Variabel & Skor KS-Z & $\boldsymbol{P}$ & Simpulan \\
\hline $\mathrm{X}_{1}$ & 1,002 & 0,487 & Data berdistribusi normal \\
\hline $\mathrm{X}_{2}$ & 2,002 & 0,06 & Data berdistribusi normal \\
\hline $\mathrm{X}_{3}$ & 0,998 & 0,494 & Data berdistribusi normal \\
\hline
\end{tabular}

\section{Uji Linearitas}

Uji linearitas dilakukan untuk mengetahui, membuktikan bahwa hubungan antar variabel yang diteliti memiliki hubungan yang linear. Dalam melakukan uji linear, peneliti melakukan analisis regresi dengan bantuan SPSS 20 dengan kriteria:

$\mathrm{H}_{0}: \hat{Y}=\mathrm{a}+\mathrm{bX}$ (regresi bersifat linear)

$\mathrm{H}_{1}: \hat{Y} \neq \mathrm{a}+\mathrm{bX}$ (regresi bersifat tidak linear)

Untuk mengetahui linearitas hubungan antara variabel Kecerdasan Logik Matematik dengan variabel Minat Belajar dilakukan dengan menggunakan SPSS 20. Dengan kriteria: jika nilai probabilitas $\mathrm{p}>0,05$ maka $\mathrm{H}_{0}$ diterima dan $\mathrm{H}_{1}$ ditolak artinya model regresi berpola linear serta jika nilai probabilitas $\mathrm{p}<0,05$ maka $\mathrm{H}_{0}$ ditolak dan $\mathrm{H}_{1}$ diterima artinya model regresi berpola tidak linear.

Tabel 3. Ringkasan Uji Linieritas

\begin{tabular}{|c|c|c|c|}
\hline Garis yang Diuji & Skor $\mathbf{F}$ & $\boldsymbol{P}$ & Simpulan \\
\hline $\mathrm{X}_{1}$ atas $\mathrm{X}_{2}$ & 1,002 & 0,487 & Model regresi berpola linier \\
\hline $\mathrm{X}_{1}$ atas $\mathrm{X}_{3}$ & 2,002 & 0,06 & Model regresi berpola linier \\
\hline $\mathrm{X}_{2}$ atas $\mathrm{X}_{3}$ & 0,998 & 0,494 & Model regresi berpola linier \\
\hline
\end{tabular}

\section{Uji Multikolinearitas}

Untuk mendeteksi apakah model regresi mengalami multikolinearitas, dapat diperiksa menggunakan VIF. VIF merupakan singkatan dari Variance Inflation Factor. Hipotesis:

$\mathrm{H}_{0}$ : Terjadi multikolinearitas antara variabel bebas

$\mathrm{H}_{1}$ : Tidak terjadi multikolinearitas antara variabel bebas

Kriteria pengujian Multikolinearitas: 
Suatu model regresi dikatakan bebas dari multikolinearitas jika:

a) mempunyai nilai VIF kurang dari 10

b) mempunyai angka tolerance mendekati angka 1

Dengan menggunakan SPSS 20 diperoleh hasil sebagai berikut:

Tabel 4. Uji Multikolinearitas

\begin{tabular}{|c|c|c|}
\hline \multirow{2}{*}{ Variabel Bebas } & \multicolumn{2}{|c|}{ Collinearity Statistics } \\
\cline { 2 - 3 } & Tolerance & VIF \\
\hline Kecerdasan Logik Matematik & 0.905 & 1.105 \\
\hline Minat Belajar & 0.905 & 1.105 \\
\hline
\end{tabular}

Berdasarkan hasil pengujian pada tabel di atas diperoleh nilai Tolerance 0.905 mendekati nilai angka 1 dan nilai Varians Inflation Factor $(\mathrm{VIF})=1.105$ kurang dari 10. Sehingga dapat dinyatakan bahwa tidak ada multikolinearitas antara kecerdasan logik matematik dan minat belajar.

\section{Pengujian Hipotesis}

Analisis korelasi digunakan untuk mencari koefisien korelasi, yang selanjutnya koefisien korelasi tersebut akan digunakan untuk menentukan koefisien jalur. Dalam menggunakan analisis korelasi, peneliti menggunakan SPSS 20 sebagai alat bantu dengan hasil sebagai berikut:

Tabel 5. Ringkasan Koefisien Korelasi (r)

\begin{tabular}{|l|c|}
\hline \multicolumn{1}{|c|}{ Hubungan Antar Variabel } & Korelasi \\
\hline Kecerdasan Logik Matematik terhadap Prestasi Belajar Matematika $\left(\mathbf{r}_{\mathbf{1 3}}\right)$ & 0,394 \\
\hline Minat Belajar Terhadap Prestasi Belajar Matematika $\left(\mathbf{r}_{\mathbf{2 3}}\right)$ & 0,426 \\
\hline Kecerdasan Logik Matematik Terhadap Minat Belajar $\left(\mathbf{r}_{\mathbf{1 2}}\right)$ & 0,308 \\
\hline
\end{tabular}

Tabel 5. Ringkasan Koefisien Jalur (p)

\begin{tabular}{|l|c|}
\hline \multicolumn{1}{|c|}{ Hubungan Antar Variabel } & Korelasi \\
\hline $\begin{array}{l}\text { Kecerdasan Logik Matematik terhadap Prestasi Belajar Matematika } \\
\left(\mathbf{p}_{\mathbf{3 1}}\right)\end{array}$ & 0,2902 \\
\hline Minat Belajar Terhadap Prestasi Belajar Matematika $\left(\mathbf{p}_{\mathbf{3 2}}\right)$ & 0,3370 \\
\hline Kecerdasan Logik Matematik Terhadap Minat Belajar $\left(\mathbf{p}_{\mathbf{2 1}}\right)$ & 0,308 \\
\hline
\end{tabular}

Berdasarkan nilai koefisien korelasi dan koefisien jalura, maka kontelasi penelitian dalam Model Analisi Jalur menjadi:

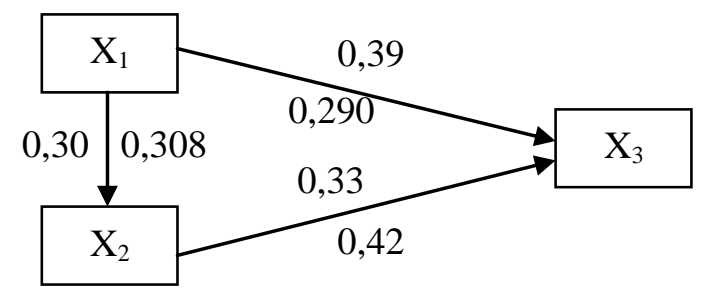

Dari koefisien jalur yang diperoleh angka yang signifikan (di atas 0,05 ). Hal ini membuktikan bahwa diagram jalur yang disusun dapat diterima, hal ini membuktikan bahwa:

1) terdapat pengaruh langsung $X_{1}$ terhadap $X_{3}$, dan juga pengaruh tidak langsung $X_{1}$ terhadap $\mathrm{X}_{3}$ melalui $\mathrm{X}_{2}$

2) Terdapat pengaruh langsung $X_{1}$ terhadap $X_{2}$

3) Terdapat pengaruh langsung $X_{2}$ terhadap $X_{3}$ 


\section{Pengujian Hipotesis Kesatu}

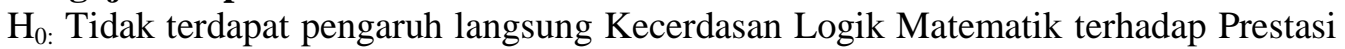
Belajar Matematika

$\mathrm{H}_{1}$ : Terdapat pengaruh langsung Kecerdasan Logik Matematik terhadap Prestasi Belajar Matematika

Berdasarkan analisis jalur diketahui bahwa koefisien jalur variabel kecerdasan logic matematik terhadap prestasi belajar matematika $\mathrm{p}_{31}=0,2902$. Dari data mentah (lampiran angka baku) diperoleh $\mathrm{s}_{31}=0 ., 0986$. Maka diperoleh nilai $\mathrm{t}_{\mathrm{h}}$ (Supardi,2012) yaitu:

$$
\begin{aligned}
& t_{h}=\frac{p_{31}}{s_{31}} \\
& t_{h}=\frac{0,2902}{0,09867} \\
& t_{h}=2,94
\end{aligned}
$$

Untuk $\alpha=0,05$ dan $\mathrm{dk}=\mathrm{n}-\mathrm{k}-1=150-2-1=147$ pada uji dua pihak diperoleh nilai $t_{\text {tabel }}=t_{t}=1,980$. Karena nilai $t_{h}>t_{t}(2,94>1,980)$ maka $H_{1}$ diterima dan disimpulkan terdapat pengaruh langsung Kecerdasan Logik Matematik terhadap Prestasi Belajar Matematika.

\section{Pengujian Hipotesis Kedua}

$\mathrm{H}_{0 \text { : }}$ Tidak terdapat pengaruh langsung Minat Belajar terhadap Prestasi Belajar Matematika

$\mathrm{H}_{1:}$ Terdapat pengaruh langsung Minat Belajar terhadap Prestasi Belajar Matematika

Berdasarkan analisis jalur diketahui bahwa koefisien jalur variabel kecerdasan minat belajar terhadap prestasi belajar matematika $\mathrm{p}_{32}=0,308$. Dari data mentah (lampiran angka baku) diperoleh $\mathrm{s}_{32}=0,09867$. Maka diperoleh nilai $\mathrm{t}_{\mathrm{h}}($ Supardi,2012) yaitu:

$$
\begin{aligned}
& t_{h}=\frac{p_{32}}{s_{32}} \\
& t_{h}=\frac{0,3370}{0,09867} \\
& t_{h}=3,42 .
\end{aligned}
$$

Untuk $\alpha=0,05$ dan $\mathrm{dk}=\mathrm{n}-\mathrm{k}-1=150-2-1=147$ pada uji dua pihak diperoleh nilai $t_{\text {tabel }}=t_{t}=1,980$. Karena nilai $t_{h}>t_{t}(3,42>1.980)$ maka $H_{1}$ diterima dan disimpulkan terdapat pengaruh langsung Minat Belajar terhadap Prestasi Belajar Matematika.

\section{Pengujian Hipotesis Ketiga}

$\mathrm{H}_{0:}$ Tidak terdapat pengaruh langsung Kecerdasan Logik Matematik terhadap Minat Belajar

$\mathrm{H}_{1}$ : Terdapat pengaruh langsung Kecerdasan Logik Matematik terhadap Minat Belajar

Berdasarkan analisis jalur diketahui bahwa koefisien jalur variabel kecerdasan minat belajar terhadap prestasi belajar matematika $\mathrm{p}_{12}=0,308$. Dari data mentah (lampiran angka baku) diperoleh $s_{12}=0,104$. Maka diperoleh nilai $t_{h}$ (Supardi,2012) yaitu:

$$
\mathrm{t}_{\mathrm{h}}=\frac{p_{12}}{s_{12}}
$$




$$
\begin{aligned}
& t_{h}=\frac{0,308}{0,104} \\
& t_{h}=2,9615
\end{aligned}
$$

Untuk $\alpha=0,05$ dan $\mathrm{dk}=\mathrm{n}-\mathrm{k}-1=150-2-1=147$ pada uji dua pihak diperoleh nilai $t_{\text {tabel }}=t_{t}=1,980$. Karena nilai $t_{h}>t_{t}\left(2,9615\right.$. > 1.980) maka $H_{1}$ diterima dan disimpulkan terdapat pengaruh langsung Kecerdasan Logik Matematik terhadap Minat Belajar.

\section{Pengujian Hipotesis Keempat:}

$\mathrm{H}_{0}$ : Tidak terdapat pengaruh tidak langsung Kecerdasan logic matematik terhadap prestasi belajar matematika melalui minat belajar

$\mathrm{H}_{1}$ : Terdapat pengaruh tidak langsung Kecerdasan logic matematik terhadap prestasi belajar matematika melalui minat belajar

Berdasarkan analisis jalur diketahui bahwa koefisien jalur variabel kecerdasan logic matematik terhadap prestasi belajar matematika melalui minat belajar $\mathrm{p}_{123}=\mathrm{p}_{21} \mathrm{X}$ $\mathrm{p}_{32}=0,308 \times 0,3370=0,1038$. Dari data mentah diperoleh:

$$
\begin{aligned}
& S g=\sqrt{\frac{\left(n_{21}-1\right) s_{21}^{2}+\left(n_{32}-1\right) s_{32}^{2}}{\left(n_{21}+n_{32}-2\right)}} \\
& S g=\sqrt{\frac{(150-1)(0,104)^{2}+(150-1)(0.09867)^{2}}{(150+150-2)}}=0,00774
\end{aligned}
$$

Maka diperoleh nilai $\mathrm{t}_{\mathrm{h}}($ Supardi, 2012) yaitu:

$$
\begin{aligned}
& \mathrm{t}_{\mathrm{h}}=\frac{p_{321}}{s_{g}} \\
& \mathrm{t}_{\mathrm{h}}=\frac{0,1038}{0,00774}=13,41
\end{aligned}
$$

Untuk $\alpha=0,05$ dan $\mathrm{dk}=\mathrm{n}-\mathrm{k}-1=150-2-1=147$ pada uji dua pihak diperoleh nilai $t_{\text {tabel }}=t_{t}=1,980$. Karena nilai $t_{h}>t_{t}(13,41>1,980)$ maka $H_{1}$ diterima dan disimpulkan terdapat pengaruh tidak langsung yang sigifikan Kecerdasan Logik

\begin{tabular}{|c|c|c|c|c|c|c|c|c|c|c|}
\hline \multirow[t]{2}{*}{ Model } & \multicolumn{2}{|c|}{$\begin{array}{l}\text { Unstandardize } \\
\text { d Coefficients }\end{array}$} & \multirow{2}{*}{\begin{tabular}{|c|}
$\begin{array}{c}\text { Standardi } \\
\text { zed } \\
\text { Coefficie } \\
\text { nts }\end{array}$ \\
Beta
\end{tabular}} & \multirow[t]{2}{*}{$\mathrm{t}$} & \multirow[t]{2}{*}{ Sig. } & \multicolumn{3}{|c|}{ Correlations } & \multicolumn{2}{|c|}{$\begin{array}{c}\text { Collinearity } \\
\text { Statistics }\end{array}$} \\
\hline & $\mathrm{B}$ & $\begin{array}{c}\text { Std. } \\
\text { Error }\end{array}$ & & & & \begin{tabular}{l|} 
Zero- \\
order
\end{tabular} & Partial & Part & $\begin{array}{c}\text { Tolera } \\
\text { nce }\end{array}$ & VIF \\
\hline (Constant) & 42,396 & 6,096 & & 6,955 & ,000 & & & & & \\
\hline 1 minat_belajar & 0,206 & 0,046 & 0,336 & 4,499 &, 000 & 0,426 & 0,348 & 0,32 & 0,905 & 1,105 \\
\hline $\begin{array}{l}\text { kecerdasan__ } \\
\text { logik_mtk }\end{array}$ & 0,273 & 0,070 & 0,290 & 3,882 &, 000 & $.0,394$ & 0,305 & $\begin{array}{r}0,27 \\
6\end{array}$ & 0,905 & 1,105 \\
\hline
\end{tabular}
Matematik terhadap prestasi belajar matematika melalui Minat Belajar.

Jika dibandingkan dengan perhitungan SPSS 20 dan perhitungan $t_{\text {hitung }}$ dengan menggunakan excel, maka didapatkan $t_{\text {hitung }}$ yang tidak berbeda jauh, seperti dapat dilihat dalam tabel berikut:

Tabel 9. Coefficients ${ }^{\mathrm{a}}$

a. Dependent Variable: prestasi_belajar_mtk 


\section{Interpretasi Hasil Penelitian}

\section{Pengaruh langsung kecerdasan logik matematik terhadap prestasi belajar matematika}

Temuan penelitian menunjukkan bahwa kecerdasan logic matematik yang diukur oleh prestasi belajar matematika siswa, menunjukkan adanya korelasi yang signifikan dan memiliki pengaruh langsung yang kuat (lebih besar dari 0,05) terhadap prestasi belajar matematika karena nilai $\mathrm{t}_{\mathrm{h}}>\mathrm{t}_{\mathrm{t}}(2,94>1,980)$.

Besarnya pengaruh langsung kecerdasan logic matematik terhadap prestasi belajar matematik adalah $\mathrm{KD}=\mathrm{P}_{13}{ }^{2} \times 100 \%=(0,2902)^{2} \times 100 \%=8,42 \%$, sisanya sebesar 91,58\% dipengaruhi oleh faktor-faktor lain di luar kecerdasan logik matematik.

Oleh karena itu untuk meningkatkan dan mengoptimalkan prestasi belajar siswa, salah satunya adalah dengan meningkatkan kecerdasan logik matematik. Berdasarkan hasil penelitian membuktikan adanya pengaruh antara kecerdasan logik matematik terhadap prestasi belajar matematika.

Faktor psikologis lain yang mempengaruhi prestasi beljar adalah intelegensi (kecerdasan). Intelegensi memainkan peranan yang cukup besar, khususnya terhadap tinggi rendahnya prestasi yang dapat dicapai oleh siswa. Biasanya siswa yang memiliki intelegensi yang tinggi maka prestasi belajar yang didapatkan juga akan tinggi. Hal ini terjadi karena siswa yang memiliki intelegensi yang tinggil akan lebih mudah dalam menyerap dan mencerna pelajaran di sekolah daripada siswa yang memiliki intelegensi yang rendah (Mulyana, 2006:190). Intelegensi atau kecerdasan bukan hanya kemampuan yang dibawa sejak lahir saja yang penting. Faktor - faktor lingkungan dan pendidikan pun memegang peranan.

\section{Pengaruh Langsung Minat Belajar Terhadap Prestasi Belajar Matematika}

Temuan penelitian menunjukkan bahwa adanya korelasi yang signifikan antara minat belajar dengan prestasi belajar matematika siswa. Hal ini dibuktikan dengan angka koefisien korelasi sebesar 0,3370 dan sig 0,000 $<0,05$ pada analisis korelasi.

Terdapat pengaruh langsung dan signifikan minat belajar terhadap prestasi belajar matematika siswa, hal ini ditunjukkan dengan adanya hasil angka koefisien jalur sebesar 0,3370 (lebih besar dari 0,05). Besarnya pengaruh langsung minat belajar terhadap prestasi belajar matematika adalah $\mathrm{KD}=\mathrm{p}_{23}{ }^{2} \times 100 \%=(0,370)^{2} \times 100 \%=$ $11,36 \%$, sisanya sebesar $88,64 \%$ dipengaruhi oleh faktor-faktor lain di luar minat belajar.

Oleh karena itu untuk meningkatkan dan mengoptimalkan prestasi belajar siswa, salah satunya adalah dengan meningkatkan minat belajar siswa dalam belajar matematika. Minat seperti yang dipahami oleh orang selama ini dapat mempengaruhi kualitas pencapaian hasil atau prestasi belajar siswa dalam bidang studi tertentu (Syah, 2010:134). Umpamanya, seorang siswa yang menaruh minat besar terhadap matematika akan memusatkan perhatiannya lebih banyak daripada siswa lainnya. Kemudian karena pemusatan perhatian yang intensif terhadap materi itulah yang memungkinkan siswa tadi untuk belajar lebih giat dan akhirnya mencapai prestasi yang diinginkan.

Minat siswa memang berbeda satu sama lain, ada yang memiliki minat yang tinggi dalam pelajaran matematika, ada juga yang memiliki minat yang rendah. Siswa yang memiliki minat yang rendah harus terus diberikan perhatian yang cukup oleh guru agar mendapatkan prestasi yang baik. Sedangkan siswa yang sudah memiliki minat belajar matematika yang tinggi, harus selalu diberikan motivasi agar dapat terus meningkatkan prestasi belajarnya (Bahri, 2011:116) 
Berdasarkan hasil penelitian dan uraian di atas membuktikan adanya pengaruh antara minat belajar terhadap prestasi belajar matematika. Berdasarkan temuan penelitian tersebut bahwa prestasi belajar matematika siswa dapat dipengaruhi oleh minat belajar.

\section{Pengaruh Langsung Kecerdasan Logik Matematik Terhadap Minat Belajar}

Temuan penelitian menunjukkan bahwa terdapat korelasi yang signifikan antara kecerdasan logik matematik dengan minat belajar. Hal ini dibuktikan dengan angka koefisien korelasi sebesar 0,308.

Terdapat pengaruh langsung dan signifikan kecerdasan logik matematik terhadap minat belajar, hal ini ditunjukkan dengan adanya hasil angka koefisien jalur sebesar 0,308 (lebih besar dari 0,05). Besarnya pengaruh langsung minat belajar terhadap prestasi belajar matematika adalah $\mathrm{KD}=\mathrm{p}_{12}{ }^{2} \times 100 \%=(0,308)^{2} \times 100 \%=$ $9,49 \%$, sisanya sebesar $90,51 \%$ dipengaruhi oleh faktor-faktor lain.

Kecerdasan logik matematik memiliki pengaruh terhadap minat belajar siswa dalam mempelajari matematik. Jika seorang siswa memiliki kecerdasan logik matematik yang tinggi, maka minat siswa tersebut untuk mempelajari matematika juga akan tinggi. Sebaliknya, jika siswa memiliki kecerdasan logik matematik rendah, maka minat belajar siswa tersebut untuk mempelajari materi matematika juga rendah.

Kecerdasan diakui ikut menentukan keberhasilan belajar seorang siswa. Dalyono seperti yang dikutip oleh Djamarah (2011:194) menyatakan bahwa seseorang yang memiliki kecerdasan yang baik umumnya mudah belajar dan hasil yang didapat akan baik, sebaliknya seseorang yang memiliki kecerdasan rendah, cenderung mengalami kesukaran dalam belajar, lambat berpikir karena minat belajarnya juga rendah.

Berdasarkan temuan penelitian tersebut untuk meningkatkan minat belajar dapat dilakukan dengan cara meningkatkan kecerdasan logik matematika. Berdasarkan hasil penelitian membuktikan adanya pengaruh antara kecerdasan logik matematik terhadap minat belajar.

\section{Pengaruh Tidak Langsung Kecerdasan Logik Matematik Terhadap Prestasi Belajar Matematika melalui Minat Belajar}

Temuan penelitian menunjukkan bahwa terdapat pengaruh tidak langsung dan signifikan kecerdasan logik matematik terhadap prestasi belajar matematika melalui minat belajar. Besar pengaruh tersebut adalah $\mathrm{P}_{12} \times \mathrm{P}_{23} \times 100 \%=0,308 \times 0,3370 \times$ $100 \%=10,38 \%$.

Berdasarkan temuan ini menunjukkan peningkatan prestasi belajar matematika dapat dilakukan melalui peningkatan minat belajar. Dengan membandingkan temuan yang lain dalam penelitian ini, besarnya pengaruh tidak langsung kecerdasan logic matematik terhadap prestasi belajar matematik melalui minat belajar lebih tinggi dibandingkan besarnya pengaruh langsung kecerdasan logic matematik terhadap prestasi belajar.

Tingkat kecerdasan siswa tidak dapat diragukan lagi sangat menentukan tingkat keberhasilan belajar siswa. Ini berarti bahwa semakin tinggi kemampuan intelegensi seorang siswa maka semakin besar peluangnya untuk meraih sukses. Apalagi jika ditambah dengan minat belajar matematika yang tinggi. Sebaliknya, semakin rendah kemampuan intelegensi seorang siswa ditambah dengan minat belajar yang rendh maka semakin kecil peluangnya untuk memperoleh sukses atau prestasi belajar yang didapatkan rendah (Syah, 2010:131). Jadi, dapat disimpulkan bahwa siswa akan mendapatkan prestasi belajar yang lebih tinggi apabila memiliki kecerdasan logik 
matematik yang tinggi, sebaliknya jika kecerdasan logik matematiknya rendah maka prestasi belajarnya juga akan rendah.

\section{PENUTUP}

\section{Simpulan}

Berdasarkan hasil penelitian dan pembahasannya, maka dapat disimpulkan:

1. Kecerdasan logik matematik memiliki pengaruh langsung yang signifikan terhadap prestasi belajar matematika siswa.

2. Minat belajar memiliki pengaruh langsung yang signifikan terhadap prestasi belajar matematika siswa.

3. Kecerdasan logik memiliki pengaruh langsung yang tidak signifikan terhadap minat belajar siswa.

4. Kecerdasan logik matematik memiliki pengaruh tidak langsung terhadap prestasi belajar matematika siswa melalui minat belajar siswa.

Saran

Berdasarkan kesimpulan dari hasil pengumpulan, pengolahan dan analisa data maka peneliti menyarankan sebagai berikut:

1. Bagi guru yang ingin meningkatkan prestasi belajar matematika siswa-siswinya hendaknya dapat menarik minat siswa dalam belajar matematika baik dengan berbagai cara agar siswa mau berkonsentrasi, memahami dan melatih kemampuan terhadap materi yang diberikan.

2. Demi tercapainya tujuan pembelajaran matematika maka pihak sekolah diharapkan agar dapat mengadakan kegiatan yang berhubungan dengan peningkatan kecerdasan logik matematik siswa.

3. Dengan melihat kelemahan-kelemahan yang ada, maka perlu dilakukan penelitian lanjutan.

\section{DAFTAR PUSTAKA}

Abdullah, Suparman I. 2012. Aplikasi Komputer dalam Penyusunan Karya Ilmiah. PT. Pustaka Mandiri.

Arikunto, Suharsimi. 2006. Prosedur Penelitian Suatu Pendekatan Praktik. Jakarta: PT. Rineka Cipta.

Campbell, Bruce, Linda Campbell dan Dee Dickinson. 2005. Metode Praktis Pembelajaran Berbasis Multiple Intelligences. Depok: Intuisi Press.

Daryani, Rismayanti. 2009. Modul Bimbingan Konseling Kelas XII. Surakarta: CV Hayati Tumbuh Subur.

Depdikbud. 2001. Kamus Besar Bahasa Indonesia. Jakarta: Balai Pustaka.

Dimyati dan Mudjiono. 2006. Belajar dan Pembelajaran. Jakarta: Rineka Cipta.

Djaali dan Pudjiono. 2008. Pengukuran dalam Bidang Pendidikan. Jakarta: PT. Grasindo.

Djamarah, Syaiful Bahri. 2011. Psikologi Belajar. Jakarta: Rineka Cipta.

Hamalik, Oemar. 2009. Proses Belajar Mengajar. Jakarta: PT. Bumi Aksara.

Hudojo, Herman. 1988. Mengajar Belajar Matematika. Jakarta: Departemen Pendidikan dan Kebudayaan.

Jensen, Eric. 2008. Memperkaya Otak: Cara Memaksimalkan Potensi Setiap Pembelajaran. Jakarta: Indeks.

Mahmud, M. Dimyati. 2002. Dasar-Dasar Sosiologi Pendidikan. Jakarta: Depdiknas.

Nazir, Moh. 2005. Metode Penelitian. Bogor: Ghalia Indonesia.

Nuryanti, Lusi. 2008. Psikologi Anak. Jakarta: PT. Indeks. 
Purwanto, Ngalim. 2010. Psikologi Pendidikan. Bandung: PT. Remaja Rosdakarya.

Riduwan, Sunarto H. 2007. Pengantar Statistika untuk Penelitian. Bandung: Alfabeta.

Sanjaya, Wina. 2010. Strategi Pembelajaran Berorientasi Standar Proses Pendidikan. Jakarta: Prenada Media Group.

Slameto. 2003. Belajar dan Faktor-Faktor yang Mempengaruhinya. Jakarta: Rineka Cipta.

Sudijono, Anas. 2004. Interaksi dan Motivasi Belajar Mengajar. Jakarta:Bumi Aksara.

Sudjana, Nana. 1995. Penilaian Hasil Proses Belajar Mengajar. Bandung: Remaja Rosdakarya.

Sugiyono. 2008. Metode Penelitian Pendidikan. Bandung: Alfabeta.

Sumarna, Cecep. 2004. Filsafat Ilmu dari Hakikat Menuju Nilai. Bandung: Pustaka Bani Quraisy.

Supardi, U.S. 2012. Aplikasi Statistika dalam Penelitian. Jakarta: Ufuk Press.

Suriasumantri, Jujun. 2005. Filsafat Ilmu. Jakarta: Pustaka Sinar Harapan.

Susanto. 2011. Filsafat Ilmu. Jakarta: PT. Bumi Aksara.

Syah, Muhibbin. 2010. Psikologi Pendidikan. Bandung: PT. Remaja Rosdakarya.

Tim Redaksi. 2010. Super Tes IQ. Jakarta: PT. Tangga Pustaka.

Uno, Hamzah B. dan Kuadrat, Masri. 2009. Mengelola Kecerdasan dalam Pembelajaran. Jakarta: PT. Bumi Aksara.

Yaumi, Muhammad. 2012. Pembelajaran Berbasis Multiple Intelligences. Jakarta: PT. Dian Rakyat. 